\title{
University Faculty Research Training and Performance: A Case from Peru
}

\author{
Shirley Simbron-Espejo ${ }^{1}$, Fanny Sanabria-Boudri ${ }^{2}$, Felix Colina-Ysea ${ }^{3,4}$, Jose Albites-Sanabria, ${ }^{4,}$ \\ ${ }^{1}$ Faculty of Business, Universidad Privada del Norte, Lima, Peru \\ ${ }^{2}$ Faculty of Education, Universidad Nacional de Educación Enrique Guzmán y Valle, Lima, Peru \\ ${ }^{3}$ Faculty of Humanities, Universidad Tecnológica del Perú, Lima, Peru \\ ${ }^{4}$ Faculty of Business, Universidad Cientifica del Sur, Lima, Peru
}

Received May 31, 2020; Revised September 1, 2020; Accepted September 11, 2020

\section{Cite This Paper in the following Citation Styles}

(a): [1] Shirley Simbron-Espejo, Fanny Sanabria-Boudri, Felix Colina-Ysea, Jose Albites-Sanabria , "University Faculty Research Training and Performance: A Case from Peru," Universal Journal of Educational Research, Vol. 8, No. 11, pp. 5053-5060, 2020. DOI: 10.13189/ujer.2020.081105.

(b): Shirley Simbron-Espejo, Fanny Sanabria-Boudri, Felix Colina-Ysea, Jose Albites-Sanabria (2020). University Faculty Research Training and Performance: A Case from Peru. Universal Journal of Educational Research, 8(11), 5053-5060. DOI: 10.13189/ujer.2020.081105.

Copyright@2020 by authors, all rights reserved. Authors agree that this article remains permanently open access under the terms of the Creative Commons Attribution License 4.0 International License

\begin{abstract}
The present study aims to understand faculty research training in private universities in Lima, Peru. The paradigm that guided the study was interpretive, under the reflexive critical approach based on introspection of the experience. The methodology was qualitative, based on the thesis and its contradiction, the antithesis, the synthesis, from Hegel's perspective. The social actors were represented by faculty from Peruvian universities with different selection criteria; sixteen professors were selected as key informants. Data were collected through assertive communication strategies, using participant observation, focus groups, and interviews as techniques. In addition, the study used different research instruments to gather information such as descriptive record sheets, reflection scripts, questionnaires, video recording being key always, as a resource. Data analysis was performed with Atlas TI software using both content analysis and grounded theory. According to the observed dimensions, research has not been promoted as a core element. There is a predominance of doing research from a positivist paradigm, and universities have updated their policies to promote research dissemination with predominance on indexed article publication. The results reveal that there were transcendental changes in research training from the multidimensionality of knowledge. Hence, private universities must promote research training as the backbone of the research work focused on its strategic research plans, where the entire university community can
\end{abstract}

investigate multiple social realities from different epistemic perspectives. Keywords Research, Training, Performance,
Paradigm, University

\section{Introduction}

The prevalence of humanistic ideas that travel the world, advocating equal opportunities to the integral development of people, has raised a concern to social equity [1]. In this context, every society tries to provide its inhabitants with basic health and education conditions. Unfortunately, these opportunities are different for each reality depending on current public policies applied in each country or region. People living conditions, access to basic resources, economic development, health promotion, and education are fundamental milestones and indicators of development of every country [2]. Obviously, the change in these opportunities goes through the development of society itself and this depends on human knowledge, which in recent years has gained importance and has been given more attention than before.

In this context, Nonaka [3] states that knowledge constitutes a core unit in men in constant interaction with their sociocultural environment, experiences lived and 
prior knowledge, creating new ways of understanding knowledge, refuting ideas or refine ideas already established. In that regard, mankind is in constant epistemic construction of knowledge, valued when it is socialized with others $[4,5]$.

Therefore, knowledge constitutes the core basis for social development, being considered a main asset within each organization. For this reason, knowledge management has positioned itself as a highly relevant aspect for the development of any organization and, in extension, of societies [6]. In particular university education plays an important role, university professors must have a series of skills and capacities to transform information into knowledge that are useful, pertinent and efficient student competences; thus, generating fundamental changes within the citizenship of society [7].

This paradigmatic vision implies a perennial training of the university professor in research, developing to the maximum of their capacities, learning styles, teaching strategies, didactic resources, communication styles, conceiving research as core processes in education and training in research, highlighting the essence of man, of the developed local and global society [8]. However, this vision seems to be utopian. Fernandez [9] states that "resistance of teachers to change and innovate is visible in the context of higher education ... there is a lack of dedication to assume a real role in order to reduce the gap between the ideal and reality in terms of their teaching practice" (p.25).

According to Fernandez, teaching practice in the formation of university teaching research seems to be submerged in repeating contents; inert, sterile and parceled focused on the transmission of knowledge that generate substantial changes in the pedagogical practice, taking the student as the epicenter of the receiving action of knowledge, contradicting the new forms and styles of teaching focused on research [9].

In this sense, understanding research as core processes in the formation of faculty, according to Rodriguez [10], deserves its revision in two epistemic perspectives. First, the role of professors as knowledge means. Second, the implementation and constant revision of plans and curricula study. In this sense, research in a university context must be implemented from criticism, self-criticism and holistic, systemic, complex, integrating, multipurpose and dynamic elements, allowing the development of new forms of knowledge, recognizing that one is facing changing scenarios that warrant its approach, multidimensional self-centered [11].

Within this frame of reference, there is a need for quantum leaps in research in university academic training. In particular, in Peru, research policies and research strategic plans have been assumed demanded by licensing and accreditation processes and not as core processes in its management, reflecting contradictions in its actions [12]. In addition, the procedural, fragmentary posture, focused on content universities seem to be present in the training plans, reflecting the research from a rigid posture and not from the freedom to investigate new knowledge, making understanding difficult to apply different research to different paradigms from the mental structures of the educational actors involved in the process.

This difficulty transcends even more when teaching and administrative workload has a great predominance in day to day faculty activities. Research time must be carried out as an individual effort of some professors; these have a direct impact on scientific production of these universities [13].

Universities in Peru have implemented several instruments and activities to foster research production among students and faculty. However, these activities seem to be focused on research procedures and statistical tools management. There is a lack of activities aiming at development of research skills from both theory and practice, thus giving teachers a new paradigmatic vision of approaching research processes not only from research, but also from the pedagogical management of the classroom, reflecting itself as a versatile strategy in the students [14].

All in all, research faculty training in universities seem to be focused on compliance of indicators regulated by licensing and accreditation, and not as investigative praxis of the university culture itself that leads to developing new paradigmatic ways of approaching research. from teacher training. In relation to the problems detected, the following question arises: How is university faculty research training carried out private universities in Lima from research faculty perspective? Does it fulfill its expectations? Can we do it better?

\section{Materials and Methods}

The paradigm that guided the investigative process was the interpretative one, under a reflexive critical approach, which allows collecting and better clarifying the meaning of the study, taking research as a permanent process. A key for this research approach is to unravel and reveal the categories and social conditions that stimulate knowledge and the shaping of the way of thinking about reality. Therefore, it is intended that social actors raise awareness of how dynamic their thoughts, arguments and reasoning are around the training of university teaching in attention to research. It is intended not only the revision of perceptions and significator, but also the understanding of their reality for their subsequent interpretation.

In that regard, the epistemic approach proposed in the research was the introspection of the experience, concatenated to critical theory as guiding frameworks to scientific knowledge and transformational processes of the mental structures. Padron [15] states "it arises from the need for emancipation, which goes through unraveling the way in which the human being is alienated and subjected through the multiple sociocultural mechanisms, including science as a power structure and domination". These processes led to considering understanding and 
interpretation as the ways of phenomenally grasping and unveiling the sociocultural symbolisms underlying the leisure- cultural relationships and processes marked in university teacher education from research.

From this position, the way of thinking of each of the key informants was subjected to critical processes and reflective self-criticism, taking faculty research training as a central problem that needs to be questioned and rethought for its transformation.

Methodologically, the three-moment dialectical circular process was followed and moved by the contradiction, proposed by Hegel quoted by Alvarez [16], "from the thesis and its contradiction, the antithesis, the solving synthesis arises that leads to initiate the changes and the transformations". That is to say, the thesis and its contradiction were guided in the research by the problematization of university teacher training in research for the contrast between ideologies and practices, which originated a contrast between the reality lived by the teachers of the private universities in Lima and new models of teacher training.

In this sense, this process was cyclical and systemic, triggered in the antithesis, in the need to originate new research training processes as elements that lead to establishing a research culture in the university. These processes gave way to synthesis, as an alternative for continuous improvement that arises from the teachers involved in the process, helping among the implicit assumptions (teachers) with the emerging reality and on these opposites an articulated understanding and a new vision of the praxis as reality, in attention to research teacher training.

It is important to highlight that, along with the thesis, antithesis and synthesis process, focus groups were established with each of the educational actors involved in the process of private universities in Lima, originating the appropriate selection of key informants of the investigative process, according to a selection criteria detailed below:

- $\quad$ Active teacher at the University.

- More than 10 years working in academia.

- A least two research articles published.

- Faculty of research methodology or thesis courses.

- Express voluntary participation in the study.

- Willingness for collaborative work.

Participants were recruited from three private universities of the faculty of business and the faculty of humanities and social sciences. Calls to participate in the study were made through university internal calls and digital media through Google forms. In total, 30 participants expressed voluntary participation in the study, but only 16 participants fully complied with all the requirements within the selection criteria.

Selection criteria were keys to the adequate selection of the research subjects who contributed from their experiences and experiences as teachers at private universities in Lima. Data, phenomena, and symbols lead to their understanding, analysis and interpretation, emerging attributes that were consistent and established by systematization axes for a better understanding of the study phenomena.

To obtain valuable data that allowed its interpretation research instruments and techniques detailed in Table 1 were applied. Assertive communication between key informants and researchers was used as a strategy, creating empathy, an environment of trust, tranquility, and respect, leading to reviving from the mental processes of key informants the research teacher training.

In this interactive dialogue, participant observation was used as a process that allowed us to register gestures, expressions, and feelings that emerged bodily because of assertive communication. Likewise, focus groups were another of the techniques used, leading to an understanding of the study phenomenon from the group structure, to understand its common sense, in attention to the training of the research teacher. For the technique of participant observation and focus groups, the descriptive record sheet and reflection scripts were used as an instrument, as a factor that allowed the data to be collected as they emerged.

In addition, the interview was used as a technique and as an instrument the questionnaire, in attention to the phenomenon related to research teacher training. This process revealed the understanding of the phenomenon from the reality experienced by teachers, generating attributes that were being redefined in axes of systematization. It is necessary to mention that, along with all the development of techniques and instruments, the sound and audio recorder was used, as resources that record all the evidence related to the investigative process, leading to its perennial review to understand the phenomenon closer to lived reality.

Table 1. Research instruments and techniques

\begin{tabular}{|c|c|c|c|}
\hline Strategy & Techniques & Instruments & Resources \\
\hline \multirow{2}{*}{ Assertive communication } & Key observation & Descriptive record sheet \\
& $\begin{array}{c}\text { Focus group } \\
\text { Interview }\end{array}$ & Questionnaire & Video recorder \\
\hline
\end{tabular}


The methodology described above was focused on landing the general question, how is research training applied at your university? From this general question we derived three systematization axes each with a main focused question: how did research teaching training originate in your university? Do you know the processes of teacher training in research from the reality of your university? What have the processes been like for doing research? Are you aware of policies established at the university for research dissemination? Being open interviews, and following assertive communication as a strategy, the process led to other open questions which were then systematized and clustered in potential emerging categories.

\section{Results}

In attention to the objective of understanding university teaching training in research in private universities in Lima, Peru, the results of the research are derived as a result of the constant communicative interactions with key informants based on reflection, criticism and self-criticism, allowing the thesis and its contradiction, antithesis and synthesis to be revealed through participant observation techniques, focus groups and the interview, finding the following findings:

Table 2. Matrix of the Group questionnaire / Closing Phase

Reflection Element Research in teacher training.

\begin{tabular}{|c|c|c|}
\hline Main questions & \multicolumn{2}{|c|}{$\begin{array}{l}\text { How did research teacher training } \\
\text { originate at your university? Describe } \\
\text { the processes of faculty training in } \\
\text { research from the reality of your } \\
\text { university. }\end{array}$} \\
\hline $\begin{array}{r}\text { Axi } \\
\text { Systeme }\end{array}$ & \multicolumn{2}{|c|}{ Research faculty training } \\
\hline Reflection Element & \multicolumn{2}{|c|}{ Research training } \\
\hline Thematic Anno & \multicolumn{2}{|c|}{$\begin{array}{l}\text { University teacher training in research } \\
\text { as a constant review process on } \\
\text { educational praxis }\end{array}$} \\
\hline \multicolumn{3}{|c|}{ Descriptive Annotations-Emerging Categories } \\
\hline & G & Gl \\
\hline $\begin{array}{l}\text { The formation of } \\
\text { research at the } \\
\text { University at a time } \\
\text { was almost zero } \\
\text { because it was not } \\
\text { given the importance it } \\
\text { had in the organization. } \\
\text { Classroom teaching } \\
\text { was more important to } \\
\text { the university than } \\
\text { doing research. This is } \\
\text { within the framework } \\
\text { of the previous } \\
\text { University Law, with } \\
\text { the new Law, there are } \\
\text { already clear intentions. }\end{array}$ & $\begin{array}{l}\text { The research } \\
\text { training has } \\
\text { always been } \\
\text { structured to the } \\
\text { understanding of } \\
\text { thesis templates } \\
\text { but has not been a } \\
\text { fundamental } \\
\text { process that } \\
\text { allows continuous } \\
\text { research training. }\end{array}$ & $\begin{array}{l}\text { Research training } \\
\text { has been focused } \\
\text { on theoretical } \\
\text { courses which } \\
\text { has generated } \\
\text { fundamental } \\
\text { changes from } \\
\text { their practice. } \\
\text { Training has not } \\
\text { meshed with } \\
\text { educational } \\
\text { processes. There } \\
\text { has been a } \\
\text { change from } \\
2014 \text { to here. }\end{array}$ \\
\hline
\end{tabular}

Table 2 describes results from descriptive and interpretative annotations related to teacher training in research. In interpreting the reflection element to training in research, it asserts that this process has been submerged in almost no way at the University, as has not been promoted training as a core element leading to promoting investigative skills in faculty. From this vision, fundamental changes are needed in Peruvian universities, specifically in research training since it must be reflected as a core and transversal axis in their educational processes. Research training must be a bastion in each University to promote, encourage, develop, and strengthen research processes where all the educational actors involved where learning to learn are the fundamental bases for developing learning communities.

From this paradigmatic view, rigid structures and pre-established formats for presenting research atrophy, a very frequent error of concept within universities, which consider formats as the only way to do research. In this sense, another negative aspect in research training is to consider theoretical courses as key training processes, although it is true, it constitutes a factor, but it does not represent the essence of doing research.

Therefore, research training must cause transcendental changes in universities and one way to start is through learning communities, research hotbeds, knowledge theory meetings, addressed from the inter, intra and trans elements multidimensional focused on the complexity of the human being.

Table 3. Matrix of the Group questionnaire / Closing Phase Reflection Element Processes of doing research.

\begin{tabular}{|c|c|c|}
\hline Main questions & \multicolumn{2}{|c|}{$\begin{array}{l}\text { What have the processes been like for } \\
\text { doing research? Narrate about what } \\
\text { paradigm has been supported to carry out } \\
\text { research. }\end{array}$} \\
\hline $\begin{array}{c}\text { Axis of } \\
\text { Systematization }\end{array}$ & \multicolumn{2}{|c|}{ Research teacher training } \\
\hline Reflection Element & \multicolumn{2}{|c|}{ Research process } \\
\hline $\begin{array}{c}\text { Thematic } \\
\text { Annotations }\end{array}$ & \multicolumn{2}{|c|}{$\begin{array}{l}\text { University teacher training in research as a } \\
\text { constant review process on educational } \\
\text { praxis }\end{array}$} \\
\hline \multicolumn{3}{|c|}{ Descriptive Annotations-Emerging Categories } \\
\hline GF1 & GF2 & GF3 \\
\hline $\begin{array}{l}\text { We have always } \\
\text { been trained to do } \\
\text { descriptive or } \\
\text { correlational } \\
\text { research. Very little } \\
\text { research has been } \\
\text { presented from } \\
\text { other types, as most } \\
\text { teachers master } \\
\text { these types of } \\
\text { research. }\end{array}$ & $\begin{array}{l}\text { I remember that the } \\
\text { greatest emphasis is } \\
\text { on population, that is, } \\
\text { the population } \\
\text { number had to be } \\
\text { greater for your } \\
\text { research to be valid. } \\
\text { In addition to } \\
\text { presenting the results } \\
\text { in table and graph to } \\
\text { reaffirm your } \\
\text { research, when there } \\
\text { are different ways of } \\
\text { presenting the results. }\end{array}$ & $\begin{array}{l}\text { There was no } \\
\text { clarity in the } \\
\text { processes of doing } \\
\text { research, since } \\
\text { each professor } \\
\text { considered that } \\
\text { criteria were } \\
\text { important and, in } \\
\text { the university, } \\
\text { there was no clear } \\
\text { research policy } \\
\text { that would } \\
\text { determine those } \\
\text { processes. }\end{array}$ \\
\hline
\end{tabular}

Table 3 describes results from descriptive and interpretative annotations related to research process in 
universities. When considering the reflection element Processes of doing research, it is evident that within the university there is a predominance of doing research from the positivist paradigm that, although the importance of developing this process is recognized, it is also necessary to approach research from other positions paradigmatic. In these current times, there is a need for multidimensional research processes that allow the study from an integral, systemic, holistic, complementary, and transformational vision, adjusted to the realities of the local, national, and global world.

Then, doing research from multidimensionality represents the approach from different study perspectives, which constitutes that there is no standard population number to do the research, but rather according to the study phenomenon, it is necessary to understand the symbols from the reality of key informants. Therefore, it is reaffirmed that it is necessary that within the universities there be research policies that promote investigative work from different social settings.

Table 4. Matrix of the Group questionnaire / Closing Phase

Dissemination of research

\begin{tabular}{|c|c|c|}
\hline Main questions & $\begin{array}{c}\text { Are you aware of policies established at } \\
\text { the university for research dissemination? }\end{array}$ \\
\hline $\begin{array}{c}\text { Axis of } \\
\text { Systematization }\end{array}$ & \multicolumn{2}{|c|}{ Research teacher training } \\
\hline Reflection Element & \multicolumn{2}{|c|}{ Dissemination of research } \\
\hline $\begin{array}{c}\text { Thematic } \\
\text { Annotations }\end{array}$ & $\begin{array}{c}\text { University teacher training in research as } \\
\text { a constant review process on educational } \\
\text { praxis }\end{array}$ \\
\hline \multicolumn{2}{|c|}{ Descriptive Annotations-Emerging Categories } \\
\hline GF1 & \multicolumn{2}{|c|}{ GF2 } \\
\hline $\begin{array}{c}\text { A clear plan has not } \\
\text { been established that } \\
\text { allows us to } \\
\text { disseminate the } \\
\text { research we do for the } \\
\text { university. Well, the } \\
\text { little we do, they do } \\
\text { not allocate us time to } \\
\text { do research. }\end{array}$ & $\begin{array}{c}\text { The rearch events } \\
\text { at the university } \\
\text { have been very } \\
\text { sporadic, which } \\
\text { means that we do } \\
\text { not disclose the } \\
\text { little research we } \\
\text { are doing. }\end{array}$ & $\begin{array}{c}\text { The research we } \\
\text { have disclosed has } \\
\text { been the product } \\
\text { of our efforts and } \\
\text { not a clear } \\
\text { university policy. } \\
\text { We publish our } \\
\text { research by } \\
\text { ourselves. }\end{array}$ \\
\hline
\end{tabular}

Table 4 describes results on interpretative annotations related to dissemination of research. It is reaffirmed that it is necessary within universities to develop strategic research plans that enables the investigative action of teachers to be stimulated and, in turn, to disseminate research results. They need attractive research incentive policies to maintain the motivation of research teachers, increasing productivity for both the university and the teacher itself.

Up today, both public and private universities have either updated or created new policies to enhance research production in teachers and students. These policies include internal funding for research projects prioritizing research from established research groups and projects that include thesis and indexed articles.

In addition, policies include funding that covers travels for international conferences as well as incentives for academics that publish articles in journals indexed in Scopus and Web of Science.

The Consejo Nacional de Ciencia, Tecnología e Innovación, a national institution that leads strategies to promote and coordinate research efforts from universities and other institutions in Peru, has activate several instruments to promote research of dissemination in teachers and students. Those instruments include different calls for research project funds as well as funding for internships for both teachers and students.

Table 5. Matrix of the Group questionnaire / Closing Phase

Epistemic revolution in research teacher training.

\begin{tabular}{|c|c|c|}
\hline Main questions & \multicolumn{2}{|c|}{$\begin{array}{l}\text { What needs to be transcended in the } \\
\text { investigative process? }\end{array}$} \\
\hline Systema & \multicolumn{2}{|c|}{ Research teacher training } \\
\hline Reflection Element & \multicolumn{2}{|c|}{$\begin{array}{l}\text { Epistemic revolution in research teacher } \\
\text { training }\end{array}$} \\
\hline $\begin{array}{l}\text { Thematic } \\
\text { Annotations }\end{array}$ & \multicolumn{2}{|c|}{$\begin{array}{l}\text { University teacher training in research as a } \\
\text { constant review process on educational } \\
\text { praxis }\end{array}$} \\
\hline \multicolumn{3}{|c|}{ Descriptive Annotations-Emerging Categories } \\
\hline C & GF2 & $C^{2} 3$ \\
\hline $\begin{array}{c}\text { You need } \\
\text { fundamental } \\
\text { changes in teacher } \\
\text { education research. } \\
\text { At the present time, } \\
\text { teachers are needed } \\
\text { who, beyond } \\
\text { mastering their area } \\
\text { of knowledge, are } \\
\text { researchers. }\end{array}$ & $\begin{array}{l}\text { The university must } \\
\text { focus its teacher } \\
\text { training plans on } \\
\text { research. We need } \\
\text { research teachers } \\
\text { who direct their } \\
\text { actions from the } \\
\text { classroom, that is, } \\
\text { with their students, } \\
\text { where training is an } \\
\text { exchange of } \\
\text { knowledge } \\
\text { between teacher } \\
\text { and student. }\end{array}$ & $\begin{array}{l}\text { In order to do } \\
\text { research from } \\
\text { different } \\
\text { investigative } \\
\text { positions, it is } \\
\text { necessary for the } \\
\text { university to } \\
\text { generate substantial } \\
\text { changes, that is, to } \\
\text { allow different } \\
\text { paradigms to be } \\
\text { tackled when } \\
\text { investigating. }\end{array}$ \\
\hline
\end{tabular}

Table 5 describes results on interpretative annotations related to epistemic revolution in research teacher training. When understanding the element of reflection Epistemic revolution in teacher training in research, it is asserted that quantum leaps are urgent in universities and in all their educational actors involved in the process. To start this process, the epistemic revolution of knowledge must become a never-ending multidimensional spiral, where the recognition of knowledge, internalization, externalization, socialization, are the central bases in management, articulating the different styles of thinking in the environment stimulating for the encounter, enjoyment and exchange of knowledge.

\section{Conclusion and Discussion}

The study was conducted to understand faculty research training at private universities in Lima, Peru. The results of the research were derived after communicative 
interactions within key informants based on reflection, criticism, and self-criticism. In this regard, four categories were revealed each of them allowing a clear understanding of faculty research training current scenario. First, research training has not been applied as a core element to promote investigative skills in faculty. There has been a focus on training in methodology theoretical aspects and thesis procedures and structures; however, research has not transcended from theory to practice to day-to-day application. Second, there is a lack of clarity in the processes of doing research as well as in the understanding of university research policies that would determine those processes. Third, professors are not fully aware of the resources and opportunities they must disseminate their research. Quantitative, descriptive, and correlational studies are the predominant designs on each of the research projects and thesis. Last, university must urgently focus on faculty research training. There is a need of research teachers who direct their actions from the classroom, with their students, where training is an exchange of knowledge between teacher and student.

From this perspective, it is assumed that the training of university teachers in research in Peru must transcend the mere fact of applying theoretical-methodological instruments, following guidelines or processes, establishing sequential schemes, for the search, reaffirmation or refutation of knowledge. It is necessary to unburden oneself from the position of following procedures to indicate that research is being done. An investigative teacher in the university field is urgently invited in the light of new knowledge to confront ideas, promote personal development, allow the freedom of the investigative spirit and together with his students, learn to read reality and act to transform it.

Understanding the training of university teachers in research framed in the context of the postmodern world surrounded by chaos and uncertainty, implies approaching their process from a more humane, complex, holistic and comprehensive vision of the multiple social realities in a space-time unit. So, from this investigative reality the condition of man in being is enhanced, as a person who learns to unlearn, to learn in the continuum of life.

To understand the synergy teaching research, in the training of university teachers, is to understand it from the multidimensionality of knowledge, reflected in the praxis from different approach processes, allowing understanding real dilemmas in an interdisciplinary way. This originates that the training of the university professor in research must promote the formulation of quality academic proposals, pertinent and with a real humanistic sense, establishing reflection in an interactive dialogical unit of being, knowing, doing, and living together.

If we see research from a critical paradigm, the historical-social journey of pedagogical processes and currents developed to date in relation to research in university teacher training, help to understand why critical pedagogy constitutes the apex of pedagogical aspects from its theoretical-methodological and the palpable need to assume it as an option within the unequal and globalized world.

According to Guanipa et al. [17], critical pedagogy has ethical, political and methodological components that vitalize man as a subject within the process; Where the subject is assumed with a critical conscience capable of recognizing himself in the world, even transforming it, reaching this consciousness, he needs a dialogical education, in which horizontal relationships are established, as well as a reflexive knowledge that is also co-constructed.

Where, a dialogue means collective construction of knowledge, far from the emitter-receiver conceptions, and in which, instead, the subjects of the process are both emitter-receiver at the same time. So, critical pedagogy supposes a personal growth of educators-learners; not as a pure formalism or activism with meaningless actions, but a reflective and transforming action.

Consequently, the dialogicity of this pedagogical current implies an educator-educator dynamic of both active and reflective exchange of their knowledge, not where only the educator is the one who decides in advance on what topic his/her lecture will provide, but that he or she inquiries into the interests of the learners who from this position are built, using for it their practical-reality duality, knowledge and critical reflection of the world, in which the educator not only respects their learners but also does not underestimate them.

Critical pedagogy is hopeful insofar as it offers the possibility of building a new world, after recognizing it within each context and with respect for cultural traditions; argument that makes it possible to establish this doctrine as an element to build a solid academic platform.

Thus, the theoretical-methodological proposal of critical pedagogy should not ignore, for its transforming development as elements, the principle of practice-theory-practice; lore; collective construction of knowledge; educational process that must start from practice; respect for cultural identity; respect to the different; dialogue as an educational base; respect for the student's knowledge; coherence; recognition of the world and of the man within it; establishing horizontal relationships; humility, love, faith and commitment; the position of man as subject of the processes of change; the assertiveness of the educator including reflexivity.

Critical pedagogy is an essential link for the construction of a new man, builder of a new world, bearing in mind that this man is the main subject of the process of change, which responds to the social needs of Peru, including Latin America; where, in addition, this new man, with a holistic-critical-dialogical approach [18].

Regarding the holistic vision in the processes of knowledge conclusion; in general terms, holistic allows us to understand events from the point of view of the 
multiple interactions that characterize it and as they occur in the real context, which leads to an integrative attitude, as well as an explanatory theory oriented towards an understanding multicausal of the processes, the protagonists and their contexts.

It is for this reason that holistics refers to the way of seeing whole things, in their totality, as a whole, in their complexity, since in this way interactions, particularities and processes can be appreciated that usually cannot be perceived when be studied separately.

The holistic approach, in fact, is a way of obtaining knowledge to classify and increase awareness of the truth of the essence or nature of the human being, as well as of his environment. With regard to the human being, he studies with a global vision the interdependent interaction of his spiritual, psychic, organic, social and energetic manifestations both internally and with his fellow men, in addition to the nature of which he is part to maintain the harmonic functional balance.

The generation of the respective theory and its incidence in the production of the referred knowledge, will be done on an object that is generally in a certain historical-concrete reality. Before assuming any postulate about the characteristics or behavior of an object, it is necessary to analyze it carefully and establish its relationship with the knowledge that is going to be produced precisely in that context.

Everything expressed implies the emergence of a mutual transcendence between the object and the subject, where each of them is introduced into the spaces corresponding to the other. This implies the interconnection between both spaces, since the perception of the object generally implies the existence of an information base, supported by data, which is internalized by the subject, capable of reflecting, organizing it mentally, achieving a high level of correspondence between perception which is achieved both from the world of facts and from the representation made of it in the world of ideas.

All this will be complemented with the meaning that the subject assigns to the received information, which allows both its reinterpretation and transformation. This translates a systematic, progressive process that involves observation, perception, abstraction, mental organization, conferring meanings, even the reinterpretation of a situation handled as information and subject to sequential transformations, constitutes the main input to generate theories and produce knowledge [19].

Consequently, when estimating holistics as the fundamental basis for the development of cognitive processes, starting from undergraduate training until the doctorate, it would be guaranteeing progress through the trans complexity of the teaching-learning processes tied to the societal conjunctures of the environment, from where the student-teacher binomial in any of its roles, so that the construction of this new platform which must fully respond to the comprehensiveness of thought, doctrines, paradigms, ideologies, to transcend with them first as human beings according to Kant's ideal and then as a society, attending to the arguments of Habermas [20].

All in all, it prevails in the university context, the need to bring about changes, social transformations and the emergence of a new teacher who overcomes the rigid sequential order institutionalized in the training process, a new conception of the teacher is needed to articulate teaching and research as medullar, systemic, holistic, integrated and indissoluble processes.

To understand the synergy teaching research, in the training of the university teacher, is to understand it from the multidimensionality of knowledge, reflected in the praxis from different approach processes, allowing to understand real dilemmas in an interdisciplinary way. This originates that the training of the university professors in research must promote the formulation of quality academic proposals, pertinent and with a real humanistic sense, establishing reflection in an interactive dialogical unit of being, knowing, doing and living together.

As mentioned earlier, economic growth is directly reflected in society, with the improvement of the living conditions of people, of families. In universities, it not only educates for economic-business development, but also for citizen training, with an impact on society.

\section{Acknowledgments}

We want to acknowledge professors and experts from different Peruvian universities whose expertise and shared knowledge contributed to the present study.

\section{REFERENCES}

[1] Summers, J. K., \& Smith, L. M., "The role of social and intergenerational equity in making changes in human well-being sustainable,”. Ambio, 43(6), 718-728, 2014.

[2] Hanushek, E. A., \& Wößmann, L., "The role of education quality for economic growth,” The World Bank, 2007.

[3] Nonaka, I. Y Takeuchi, H., “The knowledge-creating company: How Japanese Companies Create the Dynamics of Innovation,” Oxford University Press. New York-Oxford, 1995.

[4] UNESCO, Bindé, Jérôme; Matsuura, Kōichirō, "Towards knowledge societies,” UNESCO Publishing, 2005.

[5] Colina, F. y Martínez, A., "A critical look at leadership styles in contemporary organizations,” 1(1), pp. 21-27, 2019. DOI: 10.33829/emprendeytransforma-0101-2019-21-27

[6] Jaleel, S., \& Verghis, A. M., "Knowledge Creation in Constructivist Learning," Universal Journal of Educational Research, 3(1), 8-12, 2015.

[7] Sanabria Boudri, M. F., Colina Ysea, F. J., \& Albites 
Sanabria, J. L., "Phonological awareness: Analysis in children of initial education of peruvian institutions according to their family structure," Revista Arbitrada Interdisciplinaria KOINONIA, IV(8), 216-242, 2019.

[8] López-Cámara, A. B., Eslava-Suanes, M. D., González-López, I., González, H. G., \& León-Huertas, C. D., "Skills of university professor and their evaluation," In Proceedings of the Sixth International Conference on Technological Ecosystems for Enhancing Multiculturality, 175-179, 2018.

[9] Fernández, S. G. "Academic Performance in Higher Education: Challenges for the Teacher and Student Commitment," Revista Científica de la UCSA, 5(3), 55-63, 2018.

[10] Rodríguez Acasio, F., \& Colina Ysea, F. J., "Research from knowledge management in the context of national experimental universities,” KOINONIA. Revista Arbitrada Interdisciplinaria KOINONIA, I(1), 1-13, 2016.

[11] Stupnytskyy, O., "Transdisciplinary in Modern Economic Education: Approaches And Evolution,” Publishing House Baltija Publishing, 2020.

[12] Pinedo, M., Chiyón, I., \& Pérez, F., “The influence of transparency on self-evaluation as part of the university accreditation process in Peru," Procedia-Social and Behavioral Sciences, 46, 1069-1076, 2012.

[13] Romani Romani, F. R., Roque Henríquez, J., Vásquez
Loarte, T., Mormontoy Calvo, H., \& Vásquez Soplopuco, H., "Bibliometric analysis of scientific production on research national agenda in Peru 2011-2014,” Anales de la Facultad de Medicina, Vol. 77, No. 3, 241-249, 2016.

[14] Kress, T. M., “Inside the 'thick wrapper' of critical pedagogy and research,” International Journal of Qualitative Studies in Education, 24(3), 261-266, 2011.

[15] Padrón, J., "Epistemological trends in 21st century scientific research,” Cinta de Moebio. Revista de Epistemología de Ciencias Sociales, 2007.

[16] Álvarez, E., “The knowledge of man. An introduction to the thought of Hegel,” Editorial Trota. España, 2001.

[17] Guanipa Ramírez, L. F., Albites Sanabria, J. L., Aldana Zavala, J. J., \& Colina Ysea, F., "Education for citizenship and democracy: The balance of power," Iustitia Socialis. Revista Arbitrada de Ciencias Jurídicas, IV (6), 71-89, 2019.

[18] Ayala Asencio, C.E., Garro Aburto, L.L., Sanabria Boudri, F.M., Aldana Zavala, J.J., Colina Ysea, F.J., Albites Sanabria, J.L., "Intercultural competences in the research training process in a private university of Lima, Perú," Espacios, 40(44), pp. 1-13, 2019.

[19] Morín, E., “Introduction to complex thinking,” Gedisa Editorial, España, 1990.

[20] Habermas, J., "Moral conscience and communicative action,” Barcelona: Peninsula. 1998 